\title{
Custom Hire Service Business of Rice Combine Harvester in Haor Basin of Bangladesh
}

\author{
A K M S Islam¹, M G K Bhuiyan², M Kamruzzaman², M A Alam², M A Rahman³
}

\begin{abstract}
Mechanization is a vital issue to modernize agriculture. The entrepreneurship development is imperative to provide service to the farmers at an affordable price, especially in haor areas. The study was conceived to estimate the combine harvester's rental charge and payback period. Data were collected from 86 rice fields harvested by a whole-feed combine harvester (Model: Zoomlion) in Mithamain upazila under the Kishoreganj district representing haor area of Bangladesh. Land size, operational time, loss time, repair time, idle time, daily area coverage and constraints of harvester machine were also recorded to predict the business viability of combine harvester. The rental charge and payback period was calculated following standard protocol to make business venture profitable. The perception of farmers regarding the prospect of using combine harvester in harvesting has been recorded through personal interviews. The field capacity of combine harvester was observed as 0.20 ha $\mathrm{hr}^{-1}$. Field efficiency of combine harvester depended on the land size. The daily area coverage can be increased after careful selection of the plots. Fuel consumption was found $4.181 \mathrm{ha}^{-1}$. Operational consolidation is the best approach to reduce the time of movement resulting in increased daily area coverage. Seasonal use of combine harvester in one locality of the study area was observed for 22 days. The rental charge of the machine was estimated as $10,000 \mathrm{Tk} \mathrm{ha}^{-1}$ and payback period was 3.5 years for the area coverage of 40 ha rice fields. Farmers would be able to save $40 \%$ harvesting cost for the rental charge of Tk 10,000 ha-1. Combine harvester rental service has emerged as a viable business model in the haor basin. Whole-feed (Zoomlion model) combine harvester appeared as an effective, economical, and labour-saving harvesting machine in the haor region land tenure system.
\end{abstract}

Key words: Field capacity, annual use, cost and time savings, rental charge, payback period

\section{INTRODUCTION}

The haor basin in the north-eastern zone of Bangladesh is an important wetland ecosystem. Haors are large back swamp or bowl-shaped depressions between the natural levees of rivers subject to monsoon flooding every year, mostly found in north eastern part of Bangladesh, collectively known as haor basin (Miah, 2013; Irfanullah et al., 2011). Bangladesh has as many as 423 small or big haors. In the district of Sunamganj the highest number of haors (133) falls followed by Kishoregonj (122) (Alam et al., 2010). As far as the ecosystem is concerned, crop production practices, economic activities and the livelihood of haor farmers are quite different from those of other parts of the country. It is a single rice cropped area. The livelihood of this region is mostly depended on Boro rice cultivation.

In the current Boro season (2019-20), paddy has been planted in 50.34 lakh ha of land which is $2 \%$ more than the target, and produced about 20 million metric tons of paddy. About 10 percent of paddy has been planted in the districts of the haor region alone, which produces about 1.7 million metric tons of rice (Khatun, 2020). However, a major portion of Boro rice is prone to damage due to early flash flood during the harvesting period. Climate in haor areas is most vulnerable during harvesting season. Timely harvesting of the crop is very much important to get the desired yield. Harvesting operation is known as critical issues in this region due to natural calamities. It is necessary to find ways to 
harvest the crop quickly so that the damage can be reduced to a minimum level.

Rice harvesting in haor areas is a significant issue for farmers because of labourer scarcity and high labour costs leading to increased production cost during rice harvesting period. Farmers are compelled to practice delayed harvesting due to shortage of labour, which results in yield loss; sometimes incurred total loss of field crops due to natural disasters. Harvesting operation is done by manually in haor region. Plots are very far from the locality. Moreover, farm roads are absent in this areas. Head and shoulder is the only option to carry harvested crops from field to threshing yard. Threshing is done by close drum thresher. Iqbal et al. (1980) found that harvesting losses increased linearly with time, ranging from $3 \%$ in the first week to $7 \%$ in the third week after maturity of the crop. Appropriate harvesting machine is a major constrain in the haor areas. In this situation, rice combine harvester services have played an important role in the harvesting of Boro rice especially in this eco-system.

Harvesting is the process of obtaining the mature crop from the farm which involves different exercises like cutting, collecting, threshing, cleaning, and bagging. These all exercises can be performed manually and in addition to the aid of harvesting machines (Mali et al., 2015). Mechanizing those activities can serve to achieve greater efficiencies, resource conservation, and reduction in the cost of crop production (Islam et al., 2017a). Harvesting of paddy using combine harvester required 34\% labour than manual operation (Hasan, 2019). The Government of Bangladesh took serious efforts to introduce combine harvester of different makes and models having varying harvesting capacity under the farm mechanization project during 2009. Government provided funds to Bangladesh Rice Research Institute (BRRI) to procure combine harvester. BRRI and Department of
Agriculture Extension (DAE) arranged large scale demonstrations in the farmers' field to create awareness among the farmers on mechanized harvesting. Entrepreneurs purchased the combine harvester at a subsidized price and operated in the farmers' field in custom hire basis. In the meantime, DAE distributed more than 2000 combine harvesters at a subsidized price (Islam, 2018). The government recently declared $70 \%$ subsidy for farmers of the haor region, up from the previous $50 \%$, for the purchase of agriculture machinery (MoA, 2020). In Boro 2019-20 season, government has allotted Tk 200 crore as assistance to procure combine harvester and reaper (MoA, 2020). However, the combine harvester is unaffordable to most of the farmers in Bangladesh due to socioeconomic conditions. In most of the cases, it is impossible to buy at a subsidized price. On the other hand, combine harvester is season based machine and due to limited annual use, most of the time of the year it sits idle. In that case, the farmer should get the service on a rental basis. There is a need to assess the business viability of custom hire service of combine harvester in haor areas. Information on technical and economic performances offers the opportunity to accept the combine harvester in harvesting the crops. This will consequently ensure the timeliness of harvesting operation and reduce the drudgery of the farmers. However, there is no study that has been done in a while to focus on the custom hire service of rice combine harvester for farmers in haor areas.

Therefore, the study was undertaken to estimate the rental charge and payback period of the combine harvester in haor areas that it is a challenging issue in the economic aspect and factor affecting farmers' use of rice combine harvester. These results will be important for policy makers, extension officers and related agents to improve this business for farmers' benefits and use. 


\section{METHODOLOGY}

\section{Study area}

This study was conducted in Maisherkandi, Mithamain upazila under Kishoreganj district during Boro 2019-20. Crops were harvested by Zoomlion combine harvester from 16 March to 10 May 2020. Data were collected from 86 rice fields. Soft land with a water height of $25 \mathrm{~mm}$ was typically prevailed in the study region during harvest time. Most of the crops were not in standing position. Ninety percent crops were observed at an inclination of 70 degrees. Plate 1 shows field operation of Zoomlion combine harvester in study area.

\section{Technical specifications of combine harvester} Table 1 presents technical specification of Zoomlion model combine harvesters. Zoomlion model combine harvester is originally developed in China.

\section{Field performances}

Effective field capacity was calculated on the harvester's productivity under actual working conditions (ASAE Standards, 2005; Amponsah et al., 2017).

\section{Effective field}

capacity $\left(\right.$ ha $\left.^{-1}\right)=\frac{\text { Total area harvested }(\text { ha })}{\text { Total operation time }(\mathrm{h})}$

\section{Fuel consumption}

Fuel tank was refilled when fuel level goes to the minimum position. Fuel consumption was recorded after completion of each day operation and measured by weighing refilled volume.

\section{Time record}

Digital stopwatch was used to record time parameters. Time parameters included operational time, movement time from machinery shed to plot and return from plot to shed, and other time (harvester movement time from one plot to another, idle timerepairing time, time spend in unloading grain

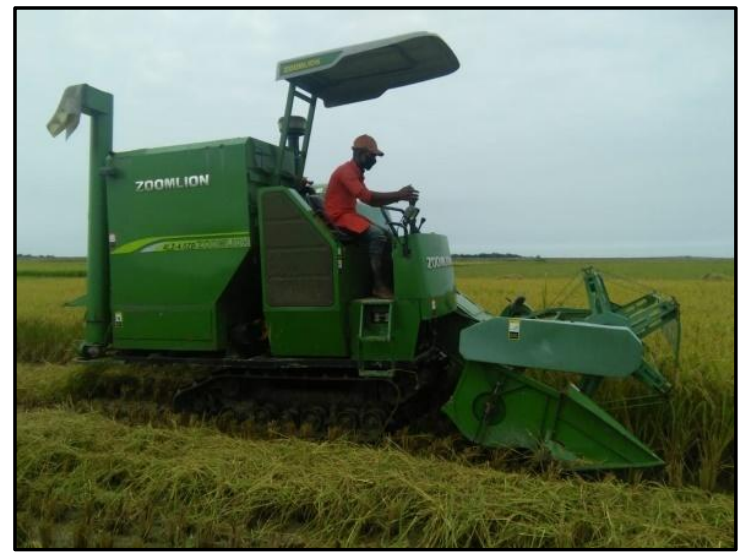

Plate 1. Field operation of Zoomlion combine harvester in haor areas.

Table 1. Technical specifications of Zoomlion combine harvester.

\begin{tabular}{ll}
\hline Item & Specification \\
\hline Name & Zoomlion \\
Model & 4LZT-4.0ZD \\
Country of origin & China \\
Price, Tk & $20,00,000$ \\
Max power, kW & 67 \\
Rated speed, rpm & 2400 \\
Total weight, kg & 3260 \\
Tracking tire & Full track \\
Minimum ground & \\
clearance, mm & 325 \\
Fuel type & Diesel \\
Fuel tank capacity, 1 & 40 \\
Cutting width, $\mathrm{m}$ & 2.0 \\
Feed quantity, kg s-1 & 4.0 \\
Grain tank capacity, kg & 650 \\
Unloading discharge, kg s-1 & 3.6 \\
Header auger & Spiral blade+ Eccentric \\
Bagging facility & Nolescopic rod rack \\
Grain cleaning (depending \\
on moisture level)
\end{tabular}


tank, unable to work due to rain, operator resting time, machinery maintenance time etc). The average of time was determined as the summation of the time in all the plots divided by the total number of the plots.

\section{Harvesting time in haor areas}

Harvesting time started from 22 April 2020 and ended on 10 May 2020. Initially, farmers harvested medium duration rice variety such as BRRI dhan 28 and BRRI dhan58. Then, the entrepreneur went for harvesting popular long duration rice variety BRRI dhan29.

\section{Economic feasibility assessment}

Costs in various segments of harvesting (both mechanized and manual methods) were classified into two groups, fixed cost and variable cost.

\section{Economic analysis}

The cost of operating the combine harvester was computed using the following equation involving the fixed and variable cost items.

$\mathrm{AC}=\mathrm{FC}+\mathrm{V}$

where,

$\mathrm{AC}=$ annual operating cost, $\mathrm{Tk}_{\mathrm{yr}} \mathrm{r}^{-1}$

$\mathrm{FC}=$ annual fixed cost, $\mathrm{Tk}_{\mathrm{yr}} \mathrm{r}^{-1}$

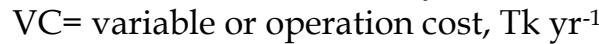

\section{Fixed cost (FC)}

It is independent of machine use and calculated on the basis of capital consumption method (CC). A capital recovery factor (CRF) was used to combine the total depreciation and interest changes into a series of equal annual payments at compound interest. The capital recovery factor can be interpreted as the amount of equal (or uniform) payments to be received for $n$ years such that the total present value of all these equal payments is equivalent to a payment of one taka at present, if interest rate is $i$. This payment is used to estimate the capital consumption for farm machinery (Hunt, 2001).
$\mathrm{CC}=(\mathrm{P}-\mathrm{S}) \mathrm{CRF}+\mathrm{S} \times \mathrm{i}$

$\mathrm{CRF}=\frac{i(i+1)^{n}}{(1+i)^{n}-1}$

where,

$\mathrm{CC}=$ capital consumption

$\mathrm{P}=$ purchase price of the combine harvester,

Tk

$\mathrm{S}=$ salvage value, $\mathrm{Tk}$

$\mathrm{CRF}=$ capital recovery factor

$\mathrm{i}=$ interest on rate of investment, $\%$

$\mathrm{n}=$ life of machine, $\mathrm{yr}$

\section{Variable cost (VC)}

These costs are associated with use of the harvester and calculated on the basis of the following equation (Hunt, 1995).

$\mathrm{VC}=\frac{\mathrm{A}}{\mathrm{C}}[(\mathrm{R} \& M) \times \mathrm{P}+\mathrm{L}$

where,

$\mathrm{A}=$ annual area coverage, ha

$\mathrm{C}=$ effective field capacity of the harvester, ha $\mathrm{hr}^{-1}$

$\mathrm{R}$ and $\mathrm{M}=$ repair and maintenance cost, $\%$

$\mathrm{P}=$ purchase price of the combine harvester, Tk

$\mathrm{L}=$ labour cost, $\mathrm{Tk} \mathrm{hr} \mathrm{r}^{-1}$

\section{Rental charge calculation and assumptions}

The rental charge for unit ( $1 \mathrm{ha}$ ) area depends on machine price, fuel, labour, transport cost, annual usage and profit. Following assumptions are taken for calculating rental charge of combine harvester;

- Purchase price of the combine harvester is Tk 20,00,000

- Government assistance is $70 \%$ of the purchase price in haor area (MoA, 2020)

- The machine is in good condition to perform its task in same rate (ha $\mathrm{hr}^{-1}$ ) without varying over its lifetime

- The bank rate for interest on investment is $12 \%$

- The repair and maintenance cost of rice harvester is taken as 5\% of its purchase price 
- The life of the harvester is considered 8 years

- Fuel price is taken as Tk $70 \mathrm{l}^{-1}$

- Operator charge is considered Tk 900 day $^{-1}$

- Cost of manual harvesting and threshing was Tk 16,500 ha-1

\section{Break-even analysis}

The break-even point (BEP) is that point at which neither profit is made nor loss incurred. The total costs of the farm enterprise would be the same as the gross income. It is important to continuously investigate the cost of operation of the farm machine. The farm's fixed costs have to be covered by the income: the higher the fixed costs, the longer it will take for the business to reach break-even and make a profit. Therefore, it is important to keep fixed costs down to a minimum level. The following formula was used to estimate the BEP of the machine.

$\mathrm{BEP}=\frac{\mathrm{FC}}{\mathrm{CR}-\mathrm{VC}}$

where,

$\mathrm{BEP}=$ break-even point, ha $\mathrm{yr}^{-1}$

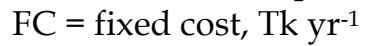

$\mathrm{VC}=$ variable cost, $\mathrm{Tk} \mathrm{ha}^{-1}$

$\mathrm{CR}=$ custom hire rate, $\mathrm{Tk}_{\mathrm{k}}{ }^{-1}$

\section{Payback period}

The payback period is the length of time required to recover the cost of an investment. The payback period of a given investment or project is an important determinant of whether to undertake the position or project, as longer payback periods are typically not desirable for investment positions. Payback period measures the time required for total cash outflows to equal total cash inflows, that is, the time required to break even.

Payback period, $\mathrm{yr}=\frac{\text { Investment }, \mathrm{Tk}}{\text { Profit }, \mathrm{Tk}^{-1}}$

\section{Data collection and analysis}

Plot length and width (m) was measured using plastic tape and recorded carefully. Daily area coverage of harvesting, travelling distance $(\mathrm{km})$ from machine shed to field, machinery trouble was collected by direct monitoring. Data were analyzed using MS-Excel 2013 and presented in tabular and graphical form.

\section{RESULTS AND DISCUSSION}

\section{Land size}

Figure 1 shows the land size of the plots in the study areas. It has been observed that the majority of the plot size exceeds $700 \mathrm{~m}^{2}$ while the plot size of just a few lands is below 700 $\mathrm{m}^{2}$. Fifty percent of the plot size is greater than $2000 \mathrm{~m}^{2}$. Larger land sizes have a major impact on the daily coverage of combine harvester areas. Islam (2020) mentioned that combine harvester having $2.0 \mathrm{~m}$ cutting width should be operated in land size having $800 \mathrm{~m}^{2}$ to get the highest performance of the machine. Daily area coverage of harvesting operation depended on land size and shape (Islam et al., 2015).

\section{Length-width $(L / W)$ ratio}

Figure 2 shows the length width ratio of rice fields under the study area. In haor regions, the $\mathrm{L} / \mathrm{W}$ ratio for 70 percent of the plots was 1.52.0. Taniyama (1975) and Islam (2018) mentioned that machinery performance dependent on the plot length-width ratio. The higher the L/W ratio lesser the turning events of the farm machine. Islam et al. (2017a) studied the plot L/W ratio in eight northern districts of Bangladesh and observed that $25 \%$ of plots belong to $\mathrm{L} / \mathrm{W}$ ratio 1.6-2.0. The plot $\mathrm{L} / \mathrm{W}$ ratio in haor areas is comparatively higher than those areas. Islam et al. (2017b) observed that the least number of turns were obtained for L/W ratio of 2-2.5 and lengthwise transplanting. With the increasing of $\mathrm{L} / \mathrm{W}$ ratio, the number of turning events 
reduced in length-wise operation and increased in width-wise transplanting layout. Lengthwise operation of farm machinery is preferable to minimize the turning events. The author suggested that the plot length should be increased by keeping the same plot size (Islam et al., 2017b). It was preferable to select the plot having $\mathrm{L} / \mathrm{W}$ ratio greater than 1.5 to operate the machine at full capacity.

\section{Variety grown in haor area}

Figure 3 shows the proportion of rice variety harvested using combine harvester in the study area. BRRI dhan29 is the largest proportion (54\%) followed by BRRI dhan 58 and hybrid dhan (14\%). BRRI dahan28 is the smallest proportion. BRRI dhan58 and BRRI dhan28 having growth duration of 150 days and 140 days respectively are grown early in the study areas. However, BRRI dhan 29 having growth duration of 160 days is widely grown in haor areas. The result revealed that BRRI dhan29 is a dominant variety in this region. BRRI dhan89 as newly released variety having similar characteristics of BRRI dhan 29 may introduce in those areas. Information on type of variety and growth duration is very much important for proper planning of the harvester operation.

\section{Daily area coverage}

Figure 4 illustrates the daily area coverage of combine harvester. Harvesting period was recorded as 22 days and harvester machine effectively operated in 17 days in haor areas due to unavoidable reason like rain, machine maintenance and unavailability of fuel. In the peak time, machine can run in day and night. Area coverage increases with careful selection of the plot. Operational consolidation i.e harvesting in adjacent plots increases the daily area coverage. Sazzad (2014) studied the field performance of DAEDONG combine harvester in Dhamrai upazila under Dhaka district during 2015 and observed that the seasonal use of combine harvester was 16 days in one locality. After completion of harvesting in haor areas, machine can be shifted to other non-haor areas to increase annual areas coverage.

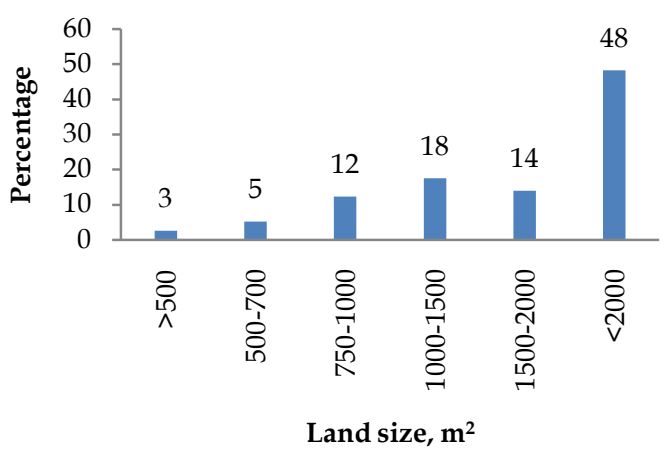

Fig. 1. Land sizes in study location.

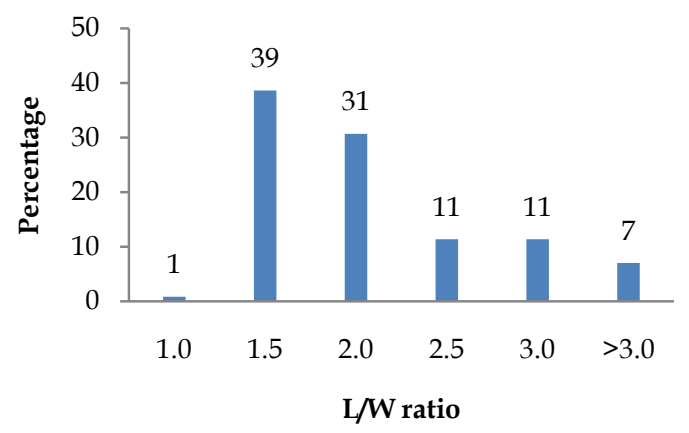

Fig. 2. Length-width ratio of rice land in haor areas.

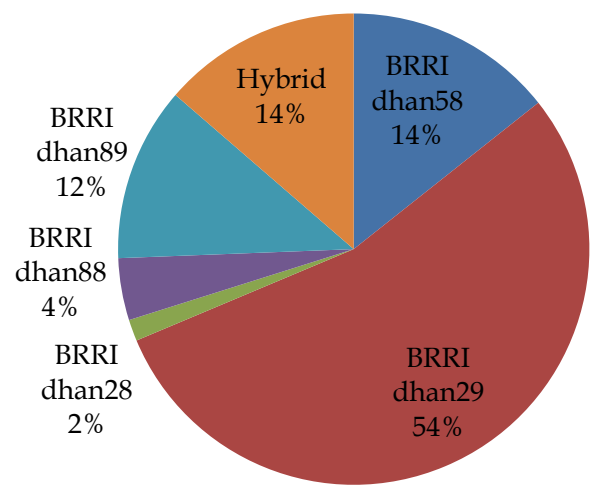

Fig. 3. Variety-wise harvesting area. 


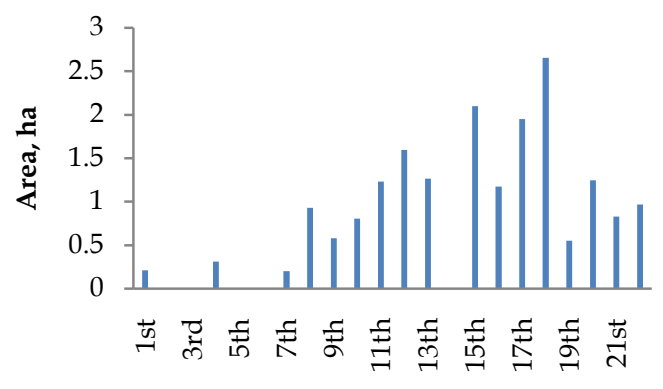

Days of operation

Fig. 4. Daily area coverage of combine harvester.

\section{Field capacity}

Figure 5 shows the field capacity in different plots in the study areas. It was found that the maximum occurrence of events at 0.17 followed by $0.19,0.21$ and 0.23 ha hr$^{-1}$ (Fig. 5). The highest field capacity (more than 0.30 ha $\mathrm{hr}^{-1}$ ) was observed in the fewer plots due to operated day and night. This might be an exceptional situation in haor areas. Field capacity having less than 0.15 ha $\mathrm{hr}^{-1}$ was observed in $6 \%$ percent plot which might be due to lodged crop, soft land, smaller size of lands etc. On average, the actual field capacity of combine harvester was observed as 0.20 ha $\mathrm{hr}^{-1}$. According to Islam (2018) field capacity increased with the increase in plot size due to the reduction of turning loss.

\section{Time distribution pattern}

Figure 6 shows the time distribution of harvesting operation. Harvesting activity was categorized as harvesting time, machinery movement time from shed to plot and return from plot to shed, plot to plot movement, and idle time. In the study area, paddy fields were very far from the machinery shed. Most of the time $(41 \%)$ spent in machinery movement including shed to plot, plot to plot. After harvesting, the machine should return from the plot to avoid stolen of spare-parts. The layout of farm roads should be re-adjusted according to Taniyama (1975) to facilitate the movement of farm machinery to each field plot without causing harm to machinery, levees and irrigation channels. Some plots were very far and damaged the irrigation channel and levees due to the machine movement. Unavoidable idle time included heavy rainfall and machine breakdown (Islam et al., 2015).

\section{Fuel consumption}

Fuel consumption depended on area coverage, distance from shed to rice field, plot to plot movement. It was estimated that total 7001 (4.18 1 ha-1) fuel was consumed to harvest 22.39 ha of land. Fuel was fully utilized in easily accessible regular shape and large size plots because of high field capacity. Additional fuel was required due to long distance of field from machinery shed. The average distance travelled in each day by the harvester from machinery shed to plot was $1.4 \mathrm{~km}$ in the study area.

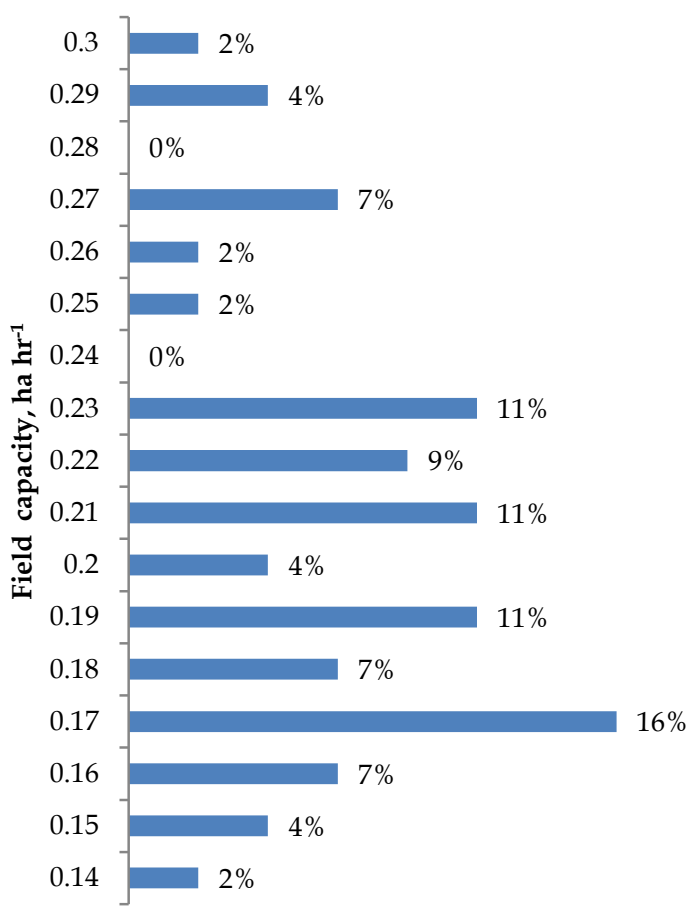

Fig. 5. Percentage of field capacity in different plots in haor areas. 


\section{Operational cost}

Figure 7 presents cost distribution of harvesting operation. Operation cost was categorized as operator's charge, fuel and oil cost, and repairing charge of the combine harvester. The fuel cost (50 percent) was the highest in items with operating costs including harvesting, movement in plot to plot, machinery shed to plot and return from plot to machinery shed. Transport cost may be minimized to operate harvester in adjacent plots. Fuel consumption may be decreased by avoiding small sizes of plots. The operating cost may be reduced through careful selection of plots having larger in size and regular in shape.

\section{Payback period}

Figure 8 was drawn from the entrepreneurs' point of view and shows the return and payback period of combine harvester. Profitability of rental service of combine harvester varied with the area coverage and rental charge. Graphs were drawn with five level of profit ranging from 10,000-12,000 Tk ha-1. Profitability started after yearly area coverage of harvesting is 22 ha with rental charge of $10,000 \mathrm{Tk}^{-1}$. The payback period would be 3.5 years for the same rental charge if yearly areas coverage is expected to 40 ha. Profit margin increases with the increase in area coverage. Business will not be viable below the annual area coverage of 40 ha for the same rental charge. The entrepreneurs can get early return on investment if offered rental charge $10,000 \mathrm{Tk} \mathrm{ha}^{-1}$ for the annual areas coverage of 50 ha. It is possible to harvest 50 ha of land in three rice seasons by Zoomlion combine harvester. Farmers would be able to save $40 \%$ harvesting cost for the rental charge of Tk 10,000 ha-1.

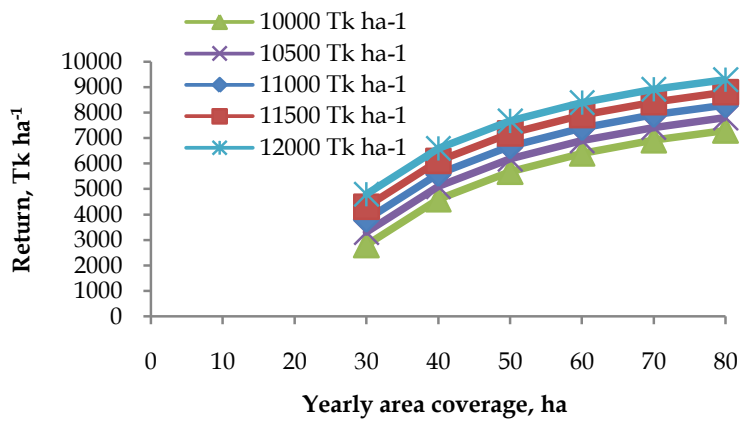

\section{Break-even area}

Figure 9 displays the mechanized harvesting costs using the Zoomlion combine harvester and manual harvesting based on relevant assumptions. Mechanized harvesting offered a total annual fixed cost of Tk 1,51,132 at an investment cost of Tk 20.00,000. However, the same conventional system procedure will involve $16,500 \mathrm{Tk}^{-1}$. Break-even area would be 36 ha for Tk 10,000 rental fee. The traditional method is intended for sickle picking, carrying paddy by head or shoulder, threshing with close drum threshers and winnowing with conventional winnower.

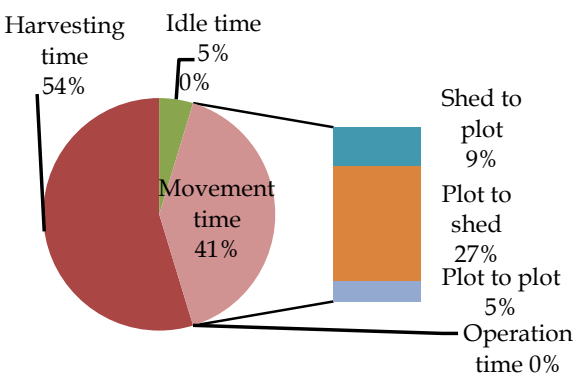

Fig. 6. Time distribution pattern in harvesting operation.

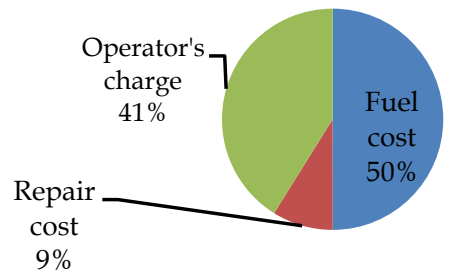

Fig. 7. Cost distribution in operation of combine harvester.

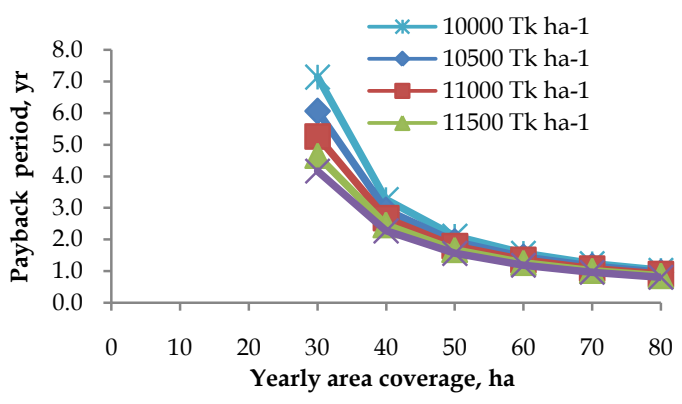

Fig. 8. Return and payback period of combine harvester. 


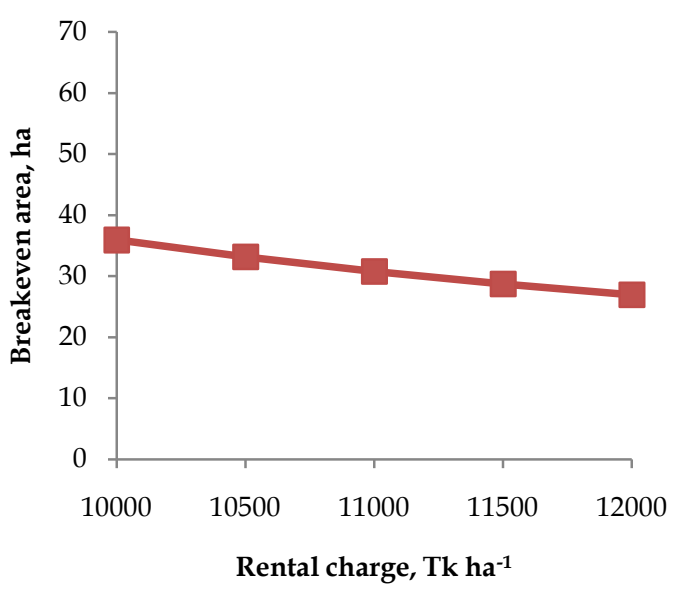

Fig. 9. Break even area with respect to rental charge.

\section{Proposed business model of harvester}

Local service providers/entrepreneurs will get the facility to purchase the combine harvester through government assistance (70\%) and provide custom hire services to the farmers at an affordable price. Before the harvesting season, the entrepreneur will contract the expected farmers to harvest the crop by combine harvester and prepare harvesting schedule.

\section{Precaution}

In haor eco-system, the market place is very far from the rice field. During the peak harvesting period, every day is a very crucial time to complete the harvesting works smoothly. Entrepreneurs as well as farmers' desire to run the combine harvester every day and night without causing any trouble. Care should be taken to investigate the combine harvester thoroughly before the harvesting season. Carefully check all moving parts, engine power, power transmission system, crawler movement, reel rotation, crop gathering, cutter bar movement and sharpness, conveyer belt movement, threshing drum rotation, blower, cleaner, auger and delivery chute. Most vulnerable parts should be identified and maintain the stock before going to the field.
Harvester model selection criteria in haor area

- Built-in grain tank facility. After harvesting, grain can be unloaded in the side of the plot.

- Bigger size having high harvesting capacity

- High capacity engine is required to develop sufficient traction force in wet land

- Low repair and maintenance time

- Parts failure frequency is minimum

- Trouble free operation

- Low noise and vibration (Operators' comfortability)

\section{Challenges/Limitation in harvesting in haor areas}

The big problem of running the harvester in haor areas is that the plots are far away from locality. There is no road for machine movement. Variety having various growth durations were grown in haor areas and matured in different time. Paddy ripens at different times as the growth duration is different for different varieties. If the grains of the inner plot ripen earlier, the machine cannot be taken to that plot over another field. Farmers can follow the synchronize farming to overcome this barrier. Harvesting schedule often broken down or delayed due to rain and hail storm.

\section{Government policy in up-scaling combine harvester}

The government has given utmost importance to mechanized agriculture to rising harvesting costs and operational timeliness. The haor region currently operates 362 combine harvesters and 1056 reapers. One hundred and sixty (160) new combine harvesters and 137 reapers were allocated for seven districts of the haor region on an emergency basis in the Boro 2019-20 season. Additionally, 220 old repairable combine harvesters and 487 reapers were repaired. The government recently adopted an action plan to promote mechanized harvesting in the region. In 2020, 
they provided $70 \%$ assistance to the haor areas and $50 \%$ aid to the other areas for harvester procurement (MoA, 2020).

\section{CONCLUSION AND RECOMMENDATION}

Combine harvester reduced the time required in harvesting, cost of harvesting and drudgery of the farmers. There is an ample opportunity to invest money on combine harvester with the government assistance and make the business profitable. The custom hire service business, however, will not be viable if the annual area covers less than 40 hectares for rental charges of 10,000 Tk ha-1. With the increase in area coverage, the profit margin increases. Larger sizes of Zoomlion model combine harvester appeared as business viable machine in haor areas of Bangladesh. Additionally, a network of haor combine harvester service operators should be formed to create approaches to promote the business in the region, to develop organizational strength, and to increase the sustainability of the business in the haor region. Larger size of land is preferable to operate the farm machinery at full capacity. Farmers can introduce synchronize farming techniques i.e. transplant the variety having the same growth duration at the same time in certain areas to facilitate the harvesting crops by machine. It may also increase daily harvest area coverage that effectively make harvesting business profitable and reduce the farmer's cost of production. The findings of study give contributions in development of entrepreneurship of combine harvester custom hire service to the farmers, particularly in haor ecosystem. However, government assistance should be continued to procure combine harvester in haor areas for timely and faster harvesting of rice crop.

\section{Acknowledgment}

This research was performed as part of project entitled "Strengthening Farm Machinery
Research Activity for Mechanized Rice Cultivation project", Bangladesh Rice Research Institute, Gazipur 1701.

\section{REFERENCE}

Alam, M S, M A Quayum, and M A Islam. 2010. Crop production in the haor areas of Bangladesh: Insights from farm level survey. The Agriculturists 8(2):88-97.

Amponsah, S K, A Addo, K A Dzisi, J Moreira, and S A Ndindeng. 2017. Performance evaluation and field characterization of the sifang mini rice combine harvester. Appl. Eng. Agric. 33(4):479-489.

ASAE 2005. Uniform terminology for agricultural machinery management. ASAE Standards St. Joseph, MI. S495.1.

Hasan, M K, MR Ali, C K Saha, M M Alam, and M M Hossain. 2019. Assessment of paddy harvesting practices of Southern Delta Region in Bangladesh. Progressive Agriculture 30(1): 57-64.

Hunt D. 2001. Farm power and machinery management, Cost determination, $9^{\text {th }}$ edition, Iowa State University press, USA.

Irfanullah, M H, M A K Azad, M Kamruzzaman, and M A Wahed. 2011. Floating gardening in Bangladesh: A means to rebuild life after devastating flood. Indian Journal of Traditional Knowledge 10(1): 31-38.

Iqbal M, G S Sheikh, and J K Sial. 1980. Harvesting and threshing losses of wheat with mechanical and conventional methods. Agricultural Mechanization in Asia, Africa and Latin America 10(3): 66-70.

Islam, A K M S. 2018. Rice mechanization in Bangladesh. Publication number 260. Bangladesh Rice Research Institute, Gazipur, Bangladesh.

Islam, A K M S. 2020. Techno-economic performance of Zoomlion combine harvester in haor areas. An unpublished report. Submitted to the Project Director, Strengthening Farm Machinery Research Activity for Mechanized Rice Cultivation project, BRRI, Gazipur.

Islam, A K M S, M T Islam, M A Rabbani, M A Rahman, and A B M Z Rahman. 2015. Com mercial mechanical rice transplanting under public private partnership in Bangladesh. Journal of Bioscience and Agriculture Research 06(01):501-511.

Islam, A K M S, M S Rahman, S R Das, T K Saha, M R Rahman, M T Islam, and M A Rabbani. 2017a. Entrepreneurial opportunity of mechanical rice transplanting service for small holder farmer in Bangladesh. Progressive Agriculture 28 (3):230-239.

Islam, A K M S, M S Kabir, and M I Hossain. 2017b. Present land size with shape and effect on the operational efficiency of rice transplanter. J. Sci. Technol. Environ. Inform 05(02):402-412. 
Khatun, A. 2020.http://agrilife24.com/2020/2018-03-1912-26-20/3399-amina-21ap.html (Accessed on 22/04/2020).

Mali P, C Sakhale, and S Shelare. 2015. A literature review on design and development of maize thresher. International Journal of New Technologies in Science and Engineering 3(9):9-14.

MoA. 2020. https://moa.gov.bd/site/news/730e50c20429-4bf4-9b47-c06b9a500027. (Accessed 20/04/2020).
Miah, M R. 2013. Enhancing food security through acclimatized species domestication in the haor region. ABC Journal of Advanced Research 2(1): 49-65.

Sazzad. 2014. Field performance of DAEDONG combine harvester. An unpublished MS thesis. Submitted to the Department of Farm Power and Machinery, Bangladesh Agricultural University, Mymensingh.

Taniyama, S. 1975. Land consolidation in paddy fields. Symposium on water management in rice fields ed. by Tropical Agricultural Research Center, Ministry of Agriculture and Forestry, Tokyo. 